\title{
特集 病院総合医セミナー「病院総合医として期待される医師像」
}

\author{
第 2 部 シンポジウム : \\ 日本型ホスピタリストモデルの構築に向けて
}

\author{
病院総合医をいかに育てるか \\ —“不断”の医療を目指す かわさき GIM の挑戦
}

\section{鈴木 貴博}

\section{当院の概要}

神奈川県の最東部にあり多摩川をはさんで東京都に 隣接する川崎市は，人口 140 万人余の政令指定都市で ある. 当院はその南部医療圈の基幹病院であり, 救命 救急センターを有する災害医療拠点病院である.

病床数 733 床, 27 診療科を有する臨床研修指定病院 で, 医師数は常勤 117 名, 非常勤として後期研修医 (専 修医）は 55 名（うち総合診療科には 19 名）, 初期研修 医は 23 名である. 1 日平均外来患者数は約 1950 名, 入院患者数は約 600 名, 救急車総受入台数は 8,390 台 である (平成 22 年度).

\section{総合診療科の創設理念}

医学の進歩に伴う医療の専門分化, 高度化により各 臟器疾患の専門医は増加しこれまで治療困難とされた 疾患が克服できるようになった，それに反し患者を全 人的に診療できる医師は減少した。 そこで, 臟器別専 門家である前に患者の全体像を把握し適切な診療を行 う病院総合医の養成が社会的に求められている. また 本当の意味での専門医は病院総合医としての素養を身 につけた上で専門分野を追究していくべきである。 そ こで当院では, “病気のみを診るのではなく悩める病 人を診る”ことのできる病院総合医の養成を行なうた め平成 10 年に総合診療科を創設した。患者を総合的 に診療することを学ぶためには, 時間的（急性期・慢 性期), 空間的 (臟器別) に患者の診療を分断するのは 得策ではない.いわば “不断”の医療を目指して当科 は発足した。これまで 14 年間に当科に在籍した医師 数は 121 名, 出身大学数は 40 大学である.

\section{プログラムの概要 ${ }^{1}$}

病院総合医の根幹は内科と救急にあると考えてい る. 原則 2 年間の内科抢よび救急救命センター ER で の後期研修であり, 内科後期研修は全て当科が担当し ている.

\section{1 ) 内科での研修}

歴史的に循環器, 呼吸器, 神経, 消化器, 腎臟, 血 液, 感染症, 膠原病, 内分泌・代謝の各専門医が内科 部長の統括のもとで分断されることなく診療してい る.したがって, 当科専修医はこの内科に入院してく る患者さんを主治医として主体的に診療を行い，常時 各分野の専門医の指導を受けることができる（図 1).

\section{A) 病棟診療}

内科・総合診療科に関わるのは一般病棟約 220 床と 救命救急センター病棟 20 床, 感染症病棟 12 床である. 緊急入院が多いため, 内科の一般病棟は臟器別ではな い. 集中治療を必要とする内科疾患の救命救急セン ター病棟への入院患者は当科が担当している.

チーム制を採用し，運用も徐々に進化している．現 在は卒後 3 年目から 5 年目 $4 \sim 5$ 名を 1 チームとして, 一般病棟に 2 チーム, 救命救急センター病棟に 1 チー ムの計 3 チームで診療している。 それぞれ毎朝 8 時 15 分からのカンファレンスで症例の共有化や議論を 通して疑問点・問題点を明確化し専門医の指導へと繋 げている，チーム制のメリットは，（1）非担当疾患の 診療も経験できる，(2) 外来・検查中でも互いの業務 を補完し合うことで集中できる，(3) 互いに教えあい 切碰琢磨できる，(4) 孤立して相談できないなどの精 神的負担がないなどである.

川崎市立井田病院 総合診療科部長（广 211-0035 神奈川県川崎市中原区井田 2-27-1)

川崎市立川崎病院 総合診療科担当部長（₹ 210-0013 神奈川県川崎市川崎区新川通 12-1） 


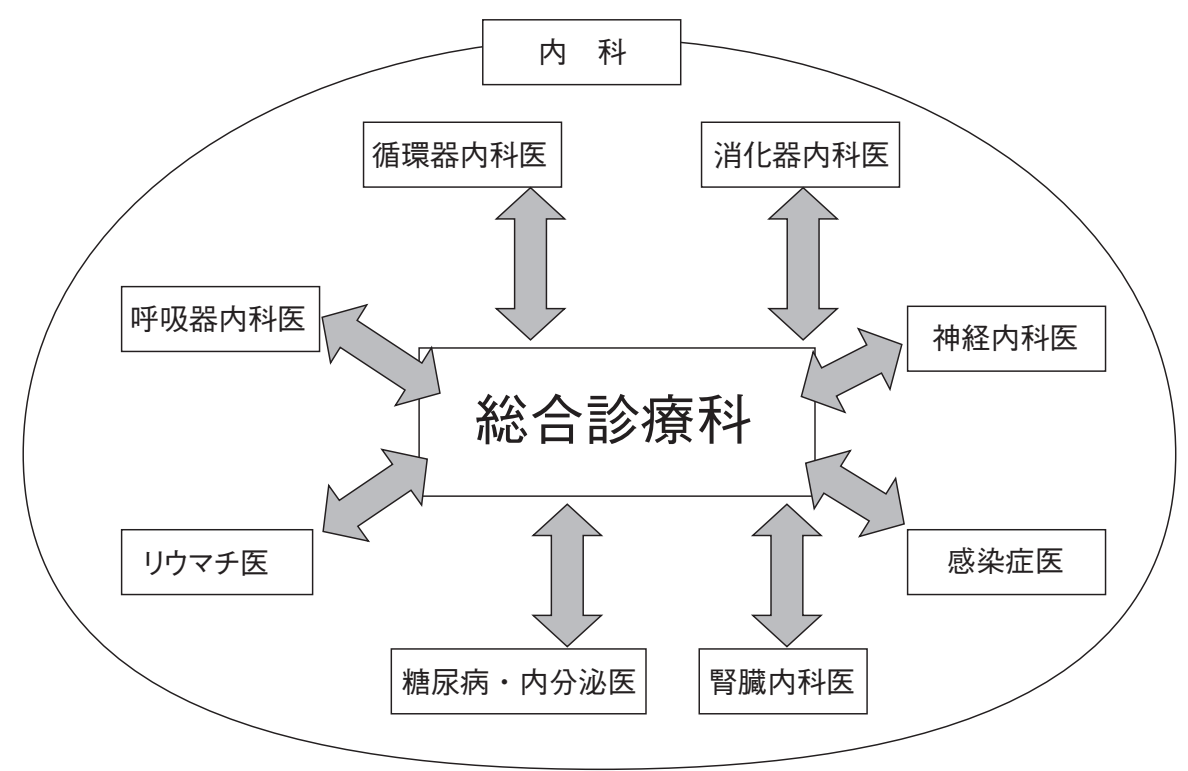

図 1 当院における内科と総合診療科の位置付け 内科は各分野の専門医および専門医を目指す主として常勤医師の集団であり，総合 診療科は後期研修医（専修医：非常勤医師）の集団である. 総合診療科の常勤医師 がアテンダントとして, 卒後 $4 \cdot 5$ 年目がリーダーとして主治医を決める. この 2 者 が専門医の指導を誘導するマネージメントを行っている.

病棟診療では内科各分野の患者を各科ローテーショ ンすることなく同時並行で診療している。これは一見 効率が悪いようであるが, 内科全般の診療を常に意識 し主病名の裏に隠れている多くの問題点を抽出し解決 する能力を身につける方法としては効果的と考えてい る.

\section{B）外来診療}

一般外来, 総合内科外来の 2 つに大別される。一般 外来では卒後 3 年目は研修開始 6 力月目より内科外来 で自らの診療枠を持ち, 入院患者の継続診療を行って いる. 総合内科外来では内科スタッフ 1 2 名と共に 専修医 1 2 名が 6 力月交代で診療している. 内科ス タッフはそれぞれの専門外来を有することから，ここ では専門医への紹介状を持参しない初診患者, 予約外 の再診患者を診療している。これにより患者に潜む問 題点を把握して必要な診療に繋げることを学んでい る. また高血圧症, 脂質異常症, 2 型糖尿病などの common disease の紹介状を有する初診患者の診療も 合わせて行っている.

\section{C) 検査}

内科に関わる検査として消化管内視鏡検査, 気管支 鏡検査, 超音波検査 (腹部・心臓), 心臓カテーテル検 査, 脳派, 筋電図, 血液透析など, 希望した検査を主 体となって研修することができる，すべての専修医に 希望する検査を研修してもらうため, 原則として6ケ
月ごとに担当する検査を組み換えている.

\section{2 ) 救命救急センターER での研修}

当院の救命救急センターは北米型救急医療システム を採用している．この中核をなすのは救急科である が，同科創設にあたり当科出身者が多く移籍したこと より関係は良好である。新年度 4 月には当科の新専修 医は救急科の新専修医と共に救急初期治療の基礎を学 ぶ. 具体的には BLS · AED の使用法, JPTEC, JATEC, ISLS などであり, いずれも ER で共に診療する のに必要な共通言語と診療手順である.

当科専修医には, 週 1 回 $\mathrm{ER}$ での研修を義務付けて いる.これは ERでの初期治療を経験することによ り, 外来から入院と継続的診療を学ぶためである.さ らに深く外傷・小手術を含めた救急診療を学ぶため, 卒後 3 年目の 3 名が 3 ケ月間ずつ救急科で研修してい る.

\section{総合医養成の提言}

市中病院の診療において, 専門医も必要であるが患 者の全体像を把握し診療を行う病院総合医が果たす役 割は極めて重要である。このような病院総合医をどの ように養成するのかが今回のシンポジウムの課題で あった。

当院では幸運にも歴史的に一内科で運用されてきた 背景があり, 内科外来や ER での診療, 入院診療, 検 
查などを通して 1 人の患者さんを継続的（“不断”）に 診療することが可能となっている. しかし, 多くの病 院では内科の各専門分野は独立しており，どのように 病院総合医を育てるか頭を悩ますところであろう。

理想を言えば内科各専門診療科に進む後期研修医と いえども，最初の 1-2 年間は総合医養成コースで学ぶ のが良い. 可能ならば内科系後期研修医は原則として 全員総合診療科という一つの集団として病棟に配属す る。病棟チーフレジデント（アテンダント）は患者を 全く受け持たないか，ごく少人数に限り，後期研修医 を集めて毎朝カンファレンスを開催し患者の持つ問題 点を抽出して指導する。 さらに専門医へコンサルトす る点を明確にして適切な指導を受けやすくするマネー ジメントを行う。内科・総合診療科の病棟があれば理 想的である. しかし，センター化された病棟でも病院 総合医の養成は可能と考える，すなわち，緊急入院患 者が多い施設では専門領域以外の患者も専門病棟に入 院してくるので，それを優先的に担当する。また，専 門病棟に入院している患者であっても，全人的な問題 や複数の臟器障害や抱えている患者は現在の高齢化社 会では多く，そのような患者も担当する。これらの診 療を通して病院総合医としてのスキルアップを図れる のではないか．また，専門医は高度な専門診療に専念 でき，その様な専門医から指導を受ける後期研修医の メリットも大きい.

\section{おわりに}

川崎市の直営する病院には, 今回紹介した川崎病院 以外に市のほぼ中央部に位置する中原区に井田病院が
ある. 井田病院では本年 5 月 1 日から新病院での診療 を開始したのを機会に診療の更なる充実のため総合診 療科を創設するとともに内科と外科が一体となった腎 泌尿器センター, 呼吸器センター, 消化器センターが 設置された．また自治体病院では唯一の存在であるか わさき総合ケアセンターでは緩和ケア・訪問診療を一 体的に運用して打り全国的にもよく知られている.

現在かわさき GIM では川崎市立 2 病院の総合診療 科を基盤として両病院の特徵を生かした魅力ある病院 総合医養成プログラムを構築しているところである.

病院総合医の養成は総合診療科単独では困難であ り, 院内の各診療科の協力が絶対に不可欠である. 病 院総合医に興味のある後期研修医は確実に存在する が，現時点に扔ける彼らの不安は何らかの専門医でな いと病院内で評価が低く identityを持ちえないという ことである，今後は，病院総合医の提供する “不断” の医療が患者の $\mathrm{QOL}$ や満足度, 他の医療者の満足度, 病院経営に寄与することを実証する中で, “不断” の医 療の提供者としての “専門性”を確立し, 魅力的な病 院総合医像を提示すことが重要と考えている。

\section{文 献}

1）宮木 大，鈴木貴博. 特集 どう発展させる病院総合 医病院総合医 地域病院での役割川崎市立川崎病 院総合診療科の後期研修 質の高い General Physician 養成の試み 病院. 2011, vol.70, no. 2, p. 124127. 